\title{
THE CHARACTERISTICS OF NATIONAL CULTURAL PECULIARITIES OF PhU WITH THE COLOR "RED" AND THEIR LINGUISTIC STRUCTURE IN ENGLISH, RUSSIAN AND UZBEK LANGUAGES
}

\author{
Charos Abdullaeva \\ Senior teacher, "Intercultural communication and tourism" department \\ TSUULL, Tashkent, Uzbekistan
}

Article DOI: https://doi.org/10.36713/epra2387

\begin{abstract}
This paper is focused on the investigation of national and cultural peculiarities of PhU, with the component "color". The research subject is national-cultural peculiarities of phraseological units with the component "red/красньй/к̧изил" in English, Russian and Uzbek languages. The article is based on general and specific examples of the meaning of phraseological units with "red/красный/құзил. Author concluded about the peculiarities of color "red/красный̈/қ̧изил" in PhU in three languages.
\end{abstract}

KEYWORDS: national and cultural specificity of PhU, linguoculturology, cognitive and linguistic-cultural essence.

\section{DISCUSSION}

Red is one of the main elements of color symbolism in national culture. Red - the color of life, sun, fertility, health and color of the beyond, chthonic and demonic characters. Red color is endowed with protective properties and is used as a shield. In ancient times, red was associated with fire, and in this sense it was reflected in the language, namely in phraseology (for example, to let the red rooster). The symbolism of red as belonging to the beyond is also expressed in the funeral rite: the deceased was bound by the thread of red. Also the red thread in ancient times was widely used as a medical remedy. Thus, against the diseases of the mother tied to the right hand of their children the red thread to make the child healthy.

Moreover, red color acts as a "talisman". For instance, a magic circle was drawn with red paint. It was necessary to stand in the middle of this circle and no uncleanness could not cause harm to the person. Additionally, people used red objects as protection against snakes, wolves, insects, mice and moles. Many mythological characters are marked in red. Exemplifying, in myths, red color were represented in folklore eyes and teeth of a witch, eyes and skin of devils, eyes of vampires, teeth and skin of mermaids.
In the ritual calendar, red is of great importance and symbolizes fertility and abundance. The ritual associated with the "red color" is performed in the wedding ceremony. Red color has long been included in the bridal garment. But the meaning of this color was "funeral and wedding". "The red dress symbolized the "mournful" dress of a girl who had "died" for her former family. That is, in this case, the red color has a negative connotation.

In the Romanesque period, the upper class wore suits of bright colors: blue, green, purple. Color in the costume had a symbolic meaning. Thus, for example, red color symbolized "blood or hellfire", and this color symbolized the royal power. This color was worn by the rich Egyptians during the Ramses. And then - the Greek infantrymen goplita to intimidate the enemy and hide the blood that came out. The clothes of the executioners were the same red color.

There is also an opinion that the name of Adam, the first man, comes from adama, which means "red earth" in Hebrew. According to apocryphal legends, Adam's blood was made of red earth, and hence the blood tint came. Red is associated with the Christian rite of communion, where wine acts as a symbol of blood, a thick red liquid that carries life. 


\section{SJIF Impact Factor: 6.260| ISI I.F.Value:1.241| Journal DOI: 10.36713/epra2016 \\ ISSN: 2455-7838(Online) \\ EPRA International Journal of Research and Development (IJRD)

As the analysis of the language material has shown, the signs presented in $\mathrm{PhU}$ with the component 'red' reflect the signs of both positive and negative orientation. In the course of the analysis of PhU values both universal and national-cultural conceptual signs have been revealed.

On this basis, it was found that the adjective "red" has its own symbolism in the phraseology. Red is present in the following phraseological combinations as a symbol of danger or, conversely, attention-grabbing: The Red Book; reds under the beds; red alert; to be/go on red alert to; red-eye flight; red-light; red baiting; catch smb. red handed; red herring; red cock; red cock will crow in his house; rus.: red book; as a red rag for a bull; red brigades.

This symbolic meaning was the factor that PhU with the "red" component associated with sensuality and sex appeal: eng.: the red light district; $a$ red hot; rus.: red lanterns. However, these PhU have a negative emotional-evaluation meaning, because they are related to the concept of prostitution, which is due to the brightness of this color and its symbolic meaning.

The negative value of red as a danger is also reflected in PhU, which expresses the sign of "difficult financial situation, debt, bad news": eng.: to be in the red; come (get) out of the red; to go to red; put in the red; go into the red; red dog; red ink; red cent not worth a red cent.

Most of the analyzed PhU in English and Russian reflect the ideas about the person and oriented in their meanings to the expressive designations of the person, the selection of his or her moral qualities, appearance, physical appearance, actions and states. The majority of PhU with the "red" component, connected with the description of a person's psychological state, have negative evaluation and denote a person in a state of aggressiveness and denote the signs associated with the concepts of "anger, aggressiveness, irritation, resentment": eng.: Red in the face; to become red in the face; red rag; red as a turkeycock; to be a bull; to see red; to be a red rag to a bull; to go as red as beet/root; to be redwood; red with anger; as red as fire; as red as streak; as red as lobster.

On the one hand, the value of red color is connected with physiological reaction of an organism (because of shame or embarrassment), and on the other hand - with the psychological attribute associated with something unworthy, indecent, immoral, shameful. Expressions with such meaning can be found in Russian, English and Uzbek languages and represent the signs associated with the concepts of "embarrassment, timidity, shyness": eng.: Red as a rose; to red as a rose; to redden to the roots of one's hair; to tern scarlet; rus: red girl; as a beautiful girl; red well done; red corner; red as cancer (beetroot, tomato); uzb: kizarib kolmoq (uyalmoq).
In Uzbek, a number of $\mathrm{PhU}$ with the component “қизил" also have negative emotional meanings and represent signs related to the concept of "incredible degree of bad": Kip-kizil ahmok (perfect fool); Kip-kizil yolgon (downright lie); Kip-kizil yolgonchi (a hopeless liar); Kip-kizil tugarmat (malignant slander). The values of these PhU are enhanced by using the duplicate color component "Kipkizil" in their composition. We also found another PhU that does not have equivalents in English and Russian languages: "Kip-kizil gusht". - no penny after penny, no stake, no yard, no beggar.

$\mathrm{PhU}$ with the "red" component can also be positive as a sign of a special day marked by a joyful event: Red-letter day; to paint the town red; rus.: red heel; red days; red sunshine. Some PhU with a red component are used to describe human appearance: a) healthy appearance: red as a cherry; and physical strength: red-blood.

The PhU with the red component also denotes the sign of eloquence in Russian and Uzbek; eng: red word, for the sake of red word; uzb: kizil suz.

$\mathrm{PhU}$ can also express concepts related to childhood and mischief in Uzbek language: kiz urtok; kiz kuzi. The peculiarity of PhU data is that they have a pronounced gender feature of femininity:

Red is also important in English culture. The red flag in the British Navy has existed since the 17th century and symbolizes a "challenge to battle". The national emblem of England is a red or scarlet rose. For thirty years, from 1455 to 1485, Lancaster, whose emblem was a red rose, waged war for the English throne with the Yorks, another dynasty (the emblem - a white rose). The war was romantically named "Red and White Rose war". The rivalry between the dynasties ended in marriage. Since then, red rose has become the national emblem of England. Red is still very popular in England. Buses and telephone booths in England are red, English soldiers wear red uniforms and there is a holiday called "Red Friday" in honor of the victory of the miners over the entrepreneurs in England. Furthermore, red color is presented almost everywhere in England. Even Napoleon said: "Red is the color of England. I can't stand the sight of it. The reason for the prevalence of red is probably that red symbolizes blood, fire, anger, war, revolution, strength and courage.

Due to the fact that red is popular in England, many EF with a component of red denote a) the realities of English linguoculture: eng.: Red, White and Blue; Red book of the exchequer; Red ribbon; Red tape; Red dog; Red cent; Red liquor; B) Professional naval accessory and patriotic attitude: eng.: The thin red line, better red than dead; shin red line; red coat; red-coated gentry, red tab; uzb: qizil ascar; qizil sokchi; qizil qushin; qizil suz. The methodical transfer also resulted in the appearance of a Red hat PhU, which denotes the title of cardinal, according to the color of the hat. A 


\section{SJIF Impact Factor: 6.260| ISI I.F.Value:1.241| Journal DOI: 10.36713/epra2016 \\ ISSN: 2455-7838(Online) \\ EPRA International Journal of Research and Development (IJRD)

number of $\mathrm{PhU}$ based on a metonymic transfer based on the colour of the skin or clothing show signs related to national origin: red shirt; red man; red shanks.

The national-cultural specificity of the Uzbek language has a huge number of $\mathrm{PhU}$, the emergence of which is due to the extra-linguistic factors of historical character, namely, the historical period of Soviet power, the symbol of which was red: Kizil burchak; Kizil choyhona; Қизил takhta (Hurmat doskasi); Kizil tuy. All aforementioned phrases are connected with the spiritual and educational work of the Soviet power and the rejection of traditional views. For example, $\mathrm{PhU}$ "Kizil tuy" means a modern wedding according to the understanding of the time, PhU "Kizil burchak" - an office where spiritual and educational work was carried out, "Kizil choyhona" - teahouse, where along with tea drinking was conducted propaganda work. It should be noted that at present, these phrases are outdated and are not used in everyday speech. Equivalent is also the "Kizil kor yokanda", expresses the category of time "never" and is based on absurdity, something that can never be.

As the analysis of language material has shown, PhU with the component "red/красный/қизил" also denotes concepts related to material culture and related to cooking. This thematic group includes $\mathrm{PhU}$ that describe food or products. They are formed by the color in which they are colored: eng.: red meat - meat (beef, lamb, etc.); red ink - cheap red wine; rus: red wine - wine from dark grapes; uzb: qizil lavlagi. Thus, the results of the analysis of PhU with the component "red" allow us to conclude that the following signs are universal for both linguocultures: a) danger; b) aggressiveness; irritation. National-cultural specifics differ in the signs associated with a) negative assessment of red and expressing signs: bad news, difficult financial situation, state of anxiety and danger; b) positive assessment of patriotism and courage, joyful event. National specifics also include the $\mathrm{PhU}$, which express a) the realities of the English linguistic culture; b) the professional affiliation to naval affairs and patriotic attitudes.

$$
\text { Bright national-cultural specificity }
$$
distinguishes PhU with the component “қизил" in Uzbek, in which the majority of PhU in contrast to English and Russian languages do not have such a pronounced negative characteristic and can be associated with positive notions.

\section{REFERENCES}

1. Aristotle1998. Nicomachean Ethics. USA: Oxford University Press.

2. Bloom, Howard, The Global Brain: The Evolution of Mass Mind from the Big Bang to the 21st Century. (2000) John Wiley \& Sons, New York. p. 10

3. Clark H., Marshall C., 1981. Definite Reference and Mutual Knowledge. Elements of Discourse
Understanding. Cambridge University Press, 1981. pp.10-63.

4. Croft W., Alan D., 2004. Cognitive Linguistics. The UK CUP.

5. Dillon J. 2000. The Question of Being in: Jacques Brunschwig, Geoffrey E. R. Lloyd (eds.), Harvard University Press, pp. 51-71.

6. Encyclopaedia Britannica 2008, Concepts in Linguistics, $C D$.

7. Evans V. 2009. How Words Mean. New York. OUP.

8. Frege, G. On Concept and Object", originally published as Über Begriff und Gegenstand in Viertelyahresschrift für wissenschaftliche Philosophie 16, 1892, pp.192-205, translated in Geach \& Black 1952 pp. 42-55. Slater, B.H. Concept and Object in Frege, 2000 (Minerva)

9. Simpson P. 2004. Stylistics. Routledge.

10. Talmy L. 2000. Toward a Cognitive Semantics, Volume 1Concept Structuring Systems. The MIT Pressp. - pp.104-118.

11. Weetaluktuk J. [http://www.helium.com] Get a Widget for this title. The concept of good and evil, positive and negative. 2002-2010 Helium, Inc.

12. Wierzbicka A. 1980. The Case for Surface Case. Arbor 1980.

13. Askol'dov S.A. Koncept i slovo // Russkaya slovesnost': Ot teorii slovesnosti $k$ strukture teksta. - M.: Academia, 1997. - pp.267-279.

14. Gruzberg L.A. Koncept // Stilisticheskiy enciklopedicheskiy slovar' russkogo yazyka. - M.: Flinta: Nauka, 2006. -p. 696

15. Karasik V. I., Slyshkin G. G. Lingvokul'turnyj koncept kak edinica issledovanija // Metodologicheskie problemy kognitivnoj lingvistiki: Sb. nauch. tr. / Pod red. I. A. Sternina. - Voronezh: VGU, 2001. s. 75 - 80. C.S. Lewis. The Chronicles of Narnia. London, Harper Collins Publishers, 2008. - 767 p. Longman. Dictionary of Contemporary English. Longman,

1. 2001 .

16. Lihachev D.S. Konceptosfera russkogo yazyka // Russkaya slovesnost'. - M.: Academia, 1997. - pp. 280-288.

17. Ljapin S.H. Konceptologiya: $k$ stanovleniyu podhoda // Koncepty. Vyp 1. - Arhangel'sk, 1997. pp.32-45.

18. Neroznak V.P. Ot koncepta $k$ slovu: $k$ probleme filologicheskogo konceptualizma // Voprosy filologii $i$ metodiki prepodavaniya inostrannyh yazykov. Omsk, 1998. - S. 80-85.

19. Stepanov U.S. Koncepty. Tonkaya plenka civilizacii. - M.: Yazyki slavyanskih kul'tur, 2007. - p.248 